\title{
Abstracts of Papers Presented at the 2016 Annual Meeting
}

SESSION 1: CONFLICT AND THE STATE IN EUROPE

\section{A Network of Thrones: Kinship and Conflict in Europe, 1495-1918}

We construct a database linking European noble kinship networks, monarchies, and wars. We show that monarchs who share kinship ties, such as through the marriages of their children, fight fewer wars. To establish causality, we exploit randomness in the timing of deaths of individuals important to the kinship network. Decreases in kinship between rulers, resulting from these deaths, are associated with an increased frequency and duration of war. Additionally, over our period of interest, we document a three-fold increase in the percentage of European monarchs with kinship ties. Together, these findings help explain the well-documented decrease in European war frequency.

Seth Gordon Benzell, and Kevin CoOKe, Boston University

\section{Habemus Papam? Polarization and Conflict in the Papal States}

We study the effect of divisions within the elite on the probability of internal conflict in the Papal States between 1295 and 1846. We assemble a new database using information on cardinals that participated in conclaves during this period, and construct measures of polarization and fractionalization based on the cardinals' birthplaces. We find that an increase of one standard deviation in our measure of polarization raised the likelihood of internal conflict by between 3 and 4 percent in a given year and by up to 24 percent in a given papacy. The effect is largest in the initial years after the conclave, to gradually vanish over time. Our results confirm that cardinals' influence on the politics of the Papal States decreased after reforms introduced between 1586 and 1588. These reforms successfully attenuated the political consequences of divisions among cardinals, the elite of one of the largest and oldest organizations.

Francisco J. Pino, University of Chile, and JORDI VIDAL-ROBERT, University of Sydney

State Formation and Social Conflict: The Political Economy of the Old Swiss Confederacy

Can judicious accession rules balance social groups and thus avoid social conflict? In this paper, I examine - theoretically and empirically - the formation of the Old Confederacy in Switzerland between 1291 and 1526. The paper shows now the political rules governing accession to the so-called "Eidgenossenschaft" mitigated costly political conflict within the Confederacy between rich city-states and rural communes. I use cooperative game theory to model the political accession game, paying particular attention to two institutions, a veto right and a two-tiered membership structure, to explain 
how social balance was maintained within the Eidgenossenschaft. Using two novel data sets, a cross-sectional data set of potential member territories, and a time series data set of region-specific instruments, the paper estimates key parameters. Analytical and numerical results show in which sense the Swiss rules dominate other possible candidate rules, and also predict expansion under alternative policies.

Jаков SchneEbacher, Yale University

\section{SESSION 2: TRANSPORTATION AND DEVELOPMENT}

\section{Structural Change: Railways, Coal and Employment Growth in Nineteenth Century England and Wales}

The transition from agricultural employment to manufacturing and services is one of the hallmarks of the industrial revolution. This paper uses sector data on male employment across more than 9,500 parishes in England and Wales to examine the effects of railways and coal on structural change. The variables of interest are the growth of employment in manufacturing, services, mining, and agriculture between 1817 and 1881, and indicators for whether parishes had coal and their distance to railway stations by 1881 . Proximity to a railway station is found to increase employment growth in all sectors with the largest effect on mining and services. Access to coal increased all employment but especially mining and manufacturing. We also use distance to principal roads in 1675 and elevation minimizing paths between major cities in 1801 as instruments for railways. The second stage results continue to show a large effect from distance to railway stations.

\section{DAN BOGART, UC Irvine, LeIGH SHAW-TAYLOR, and Max SATChell, University of Cambridge}

\section{Transportation Networks and the Geographic Concentration of Industry}

This paper examines the effect of expanding transportation networks on changes in industry location within the United States. I use the construction of the Interstate Highway System, from 1962 to 1997, to measure how improvements in transportation infrastructure and market access alter industry concentration. To address the endogenous placement of highways, I instrument for eventual highway locations using a military map designed after the WWI. To address the endogeneity surrounding the timing of highway construction, I use a network theory algorithm to predict when each segment of the highway network should have been constructed. Results indicate the expansion of transportation infrastructure led to substantial employment growth in highway counties. This employment growth was concentrated in fewer industries and induced highway counties to specialize more after the expansion of interstate highways. The results demonstrate that expanding transportation networks are important for reshaping the spatial arrangement of economic activity. 
Moving to Opportunity: Railroads, Migrations, and Economic Mobility

Persistent regional inequalities can explain part of the association between the economic outcomes of parents and their children. The strength of this influence will in turn depend on the cost of geographic mobility. In this paper, I exploit the expansion of the railroad network in nineteenth century Argentina to study the relationship between migration costs, migrations, and economic mobility. I take advantage of newly collected data linking a large sample of males across the 1869 and 1895 national censuses of population of Argentina. I find a large effect of railroad construction on geographic mobility. In addition, I find that internal migrations were associated with higher rates of intergenerational occupational mobility.

SAntiago PÉrez, Stanford University

SESSION 3: THE CIVIL WAR: LONG-RUN IMPACT

\begin{abstract}
The Effect of Fathers' Wealth on Sons' Adult Outcomes in the Nineteenth Century: Evidence from the Civil War
\end{abstract}

We use the expropriation of slave wealth and changes in the value of land after the Civil War to estimate the effect of fathers' wealth on sons' income in the U.S. South. Pre-war real estate wealth positively predicts post-war household wealth, especially in counties with stable or rising land prices, but that slave wealth does not. Correspondingly, sons' occupation-based income in 1880 is increasing in fathers' 1860 real estate wealth, but not in his slave holdings. Sons with wealthy fathers were also more likely to move to a city and move up the occupational ladder outside of agriculture. We instrument for total household wealth after the war with the slave share of total wealth before the war and with war-related changes in county land prices. Our estimates imply an elasticity between fathers' wealth and sons' income of 0.2 , a figure that sits between existing nineteenth century estimates and modern figures.

Philipp Ager, University of Southern Denmark, Leah Boustan, UCLA, and KATHERINE ERIKSSON, UC-Davis

\title{
The Long-Run Effects of Losing the Civil War: Evidence from Border States
}

This paper provides the first estimates of the long-term effects of serving on the losing side of the American Civil War on migration, health, and occupational outcomes. We compare men who served in the Confederate Army with their men who served in the Union army in the border state of Kentucky, which contributed significant numbers of soldiers to both armies. To create the dataset, we collected the universe of existing Union and Confederate enlistees from Kentucky and matched men to their pre- and post-war occupations and place of residence using the 1860 and 1880 censuses. Our findings show that Confederate soldiers were positively selected from the Kentucky population prior to the onset of the conflict. We demonstrate strikingly different postwar migration patterns between Union and Confederate veterans and show how leaving 
Kentucky erased the socioeconomic disadvantage faced by Union veterans. Our results suggest that the decision to serve on the Union or Confederate side created lasting social divisions between otherwise similar men, and that these divisions had diverse economic consequences.

SHARI J. Eli, University of Toronto,

Laura Salisbury, York University, and AlLison SHERTZer, University of Pittsburgh

The Civil War Revisited: Losing World Leadership, Gaining Emancipation, Widening Northern Inequality

This paper uses our newly estimated social tables for 1860 and 1870 to show the following: First, the Civil War and emancipation produced America's greatest redistribution of income and wealth in our history. Second, the great rise in inequality from 1790 to 1860 continued in the North during the Civil War decade. Third, the war cost America enough to erase its large pre-war per capita income lead over Britain. Fourth, the decade completed the South's two-century reversal of fortune, converting America's richest region into its poorest. The Civil War raised incomes of the freed slaves, by about 30 percent, while their labor force participation dropped toward that of whites. The paper also reports (in an Appendix) new state-level income and wealth data for 1860 and 1870.

Peter H. Lindert, UC-Davis, and JeFFrey G. Williamson, Harvard and Wisconsin

\section{SESSION 4: BANKING RISK, POLICY AND INSTITUTIONS}

\section{Double Liability in a Branch Banking System: Historical Evidence from Canada}

We investigate the effects of the abolition of double liability requirement imposed on bank shareholders in Canada on bank risk-taking and lending behavior. Under the double liability rule, the shareholders of a bank were liable up to twice the amount of their subscribed shares in the case of bankruptcy. With the establishment of the Bank of Canada in 1934, the double liability requirement became less stringent and depended on the pace of the redemption of notes in circulation issued by the individual chartered commercial banks. Using historical balance sheet and accounting data, we show that the abolition of double liability was not accompanied by increased bank risk taking in Canada. Our findings are consistent with the literature that focuses on uniform regulations and nationwide branching as key financial stability elements in Canada.

ANNA GRODECKA,

Sveriges RiksBank, and Antonis Kotidis, University of Bonn 


\section{Stealing Deposits: Deposit Insurance, Risk-Taking, and the Removal of Market Discipline in Early Twentieth Century Banks}

Deposit insurance reduces liquidity risk by removing the incentives of depositors to withdraw from banks when concerned about insolvency risk. However, it also can increase insolvency risk by encouraging reckless behavior by insured banks. Unlike modern systems that cover virtually all depository institutions and are installed in a single year, only a handful of the U.S. states installed deposit insurance laws, those laws only applied to some depository institutions within those states, and the dates of the passage and implementation of deposit insurance differ across states. These experiments thus present a unique testing ground for investigating the effect of deposit insurance. We show that deposit insurance increased risk by removing market discipline that had been constraining erstwhile uninsured banks. Insured banks increased their insolvency risk, and competed aggressively for the deposits of uninsured banks operating nearby.

\section{Charles W. Calomiris, Columbia University, and MATTHEW JAREMSKI, Colgate University}

\section{Lending Money to People across the Water": The British Joint Stock Banking Acts of 1826 and 1833, and the Panic of 1837}

I argue that the Panic of 1837 was in large part driven by bank liberalization in the United Kingdom, which triggered reflation and looser credit. In the context of the rapid growth in the United Kingdom and United States of the 1830s, this then led to a credit boom and a flow of specie to the United States. In particular, while nominal interest rates stayed stable, short-term real interest rates dipped to very low levels. The Bank of England, confused by nominal rates, allowed bullion levels to fall too low and accidentally facilitated the now well-established rapid accumulation of specie in the United States from 1830 to 1836 . By the 1840s the Bank had adjusted its policies to prevent this particular problem. This builds on the arguments of Jenks, Macesich, Temin, and Rockoff regarding the inflation of the 1830 s, providing a specific cause for the specie accumulation in the United States.

Geoffrey Fain Williams, Transylvania University

\section{SESSION 5: TRADE AND MIGRATION IN FORMAL AND INFORMAL EMPIRE}

\section{Atlantic Slavery's Impact on European Economic Development}

The economics literature on Atlantic slavery attests to its negative long-run impact on development outcomes in Africa and the Americas. What was slavery's impact on Europe? I examine the effect of a major component of slavery, the Atlantic slave trade, on European economic development from 1500-1850. By linking data from the TransAtlantic Slave Trade Database to historical city population statistics for Europe, I find that a 10 percent increase in slaving voyages is associated with a 0.5 percent increase in 
population for cities within $65 \mathrm{~km}$ of the coast. I instrument for participation in the slave trade using sailing distances to the West African coast interacted with time to capture developments in shipping technology. Results are robust to restricting the analysis to Britain and including controls for overall U.K. trade volumes.

Ellora Derenoncourt, Harvard University

\section{The Long-Run Influence of Institutions Governing Trade: The Case of Colonial and Pirates' Ports in Mexico}

In this paper we examine the long-term development impact of legal versus illegal overseas trade in colonial Mexico. While there is ample evidence that free commercial activity may lead to sustained economic benefits, it is unclear whether these effects are driven by commercial activity per se or by the accompanying state institutions that positively impact development (e.g., tax collection and legal enforcement). Using historical sources on the presence of smuggling and piracy in Mexican coasts from the sixteenth to eighteenth century we find that the presence of trade, either in its legal or illegal form, leads to significantly better development outcomes compared to neighboring areas where such activities were absent. Results are robust to instrumenting trade with natural harbors and are not driven by a mechanical effect of carrying out trade in the present, by the length of colonial presence, or by substantial geographical differences. These findings suggest that the positive impact of illegal trade may have compensated for the damaging effects of a weaker state presence and the culture of illegality surrounding it.

\section{Daphne Álvarez Villa, Oxford University, and JENNY GUARDADO, Georgetown University}

\section{The Long-Run Development Impacts of a Guest Worker Program: Evidence from the Bracero Program}

The Bracero Program was a historical guest worker program between Mexico and the United States that saw the temporary migration of nearly five million agricultural workers to the United States. These guest worker programs benefit the host country with cheaper labor and the sending communities with influxes of cash earned abroad. The Bracero Program provides an opportunity to understand the long-term development impact of such a policy. I compare the adult outcomes of those children who were treated with exposure to the program to those children who were not exposed. I utilize two methods to isolate plausibly exogenous variation and estimate this effect. One is a family fixed effects model that compares siblings, and the other is a differencein-differences model that exploits a natural experiment in the institutional history of the program. Positive effects in the long run provide further evidence of guest worker programs as good development policy. 


\section{SESSION 6: SCIENCE AND INNOVATION}

\section{Women in the Scientific Workplace: Life Course Experiences of Female Scientists in the Early Twentieth Century}

This paper investigates the life course trajectories of women in social and natural science fields in early-twentieth-century America. Historical work has richly documented the strategies small groups of women used to enter the heavily masculine realm. We set these studies in a large context by examining the factors that influence women's participation in science fields. Using newly released full count data from the 1940 U.S. Census, we have identified almost 9,000 educated women working as research scientists, engineers, university professors, and lab technicians. In addition to using the 1940 census data, we link these female scientists to the four previous decennial censuses using preliminary full-count IPUMS census data. We use this longitudinal data on the scientists and other educated women to estimate the effect of family, geography, and other characteristics on entering the sciences in the early twentieth century.

\section{Margaret Charleroy, University of Warwick, and Katie GenadeK, University of Minnesota}

\section{The Responsiveness of Inventing: Evidence from a Patent Fee Reform}

Do financial incentives induce inventors to innovate more? I exploit a large reduction in the patent fee in the United Kingdom in 1884 to distinguish between its effect on increased efforts to invent, and a decrease in patent quality due to a lower quality threshold. To analyze the impact on innovation I create a detailed new dataset of 54,000 British inventors with renewal information for each patent. In the longer run highquality patenting increases by more than 100 percent, and the share of new patents due to greater effort accounts for three-quarters of the pre-reform share of high-quality patents. To test for the presence of credit constraints I generate two asset proxies from inventor names and addresses, and find a larger innovation response for inventors with lower assets. These results indicate efficiency gains from decreasing the cost of inventing and in addition, from relaxing credit constraints.

Alice Kuegler, University of Cambridge

Effects of Copyrights on Science: Evidence from the WWII Book Republication Program

This paper investigates how copyrights - and variation in book prices-influence follow-on science that builds on copyrighted work. The United States 1942 Book Republication Program (BRP) licensed German-owned science books to U.S. publishers, who sold exact copies at a lower price. To investigate the effects of the BRP on follow-on science, we compare citations to BRP books by new scientific publications with citations to Swiss science books (that were not available for licensing). This analysis indicates that a 10 -percent reduction in price led to a 38 percent increase in 
citations. We also find that the impact of copyrights is larger for disciplines that depend more on human compared with physical capital, such as math compared with chemistry. Data on library holdings show that books with larger price reductions became more evenly diffused. Patent data indicate that the BRP was associated with a 62 percent increase in U.S. invention.

Barbara Biasi, Stanford University, and Petra Moser, NYU

\section{SESSION 7: WATER QUALITY AND ECONOMIC DEVELOPMENT}

\section{For Want of a Cup: The Rise of Tea in England and the Impact of Water Quality on Economic Development}

This paper explores the impact of water quality on long-run economic development by exploiting a natural experiment: the rise of tea consumption in eighteenth century England. This resulted in an unintentional increase in consumption of boiled water, thereby reducing mortality rates. The methodology uses two identification strategies tying areas with lower initial water quality to larger declines in mortality rates after tea drinking became widespread and following larger volumes of tea imports. Results are robust to the inclusion of controls for income and access to trade. The hypothesis is further bolstered by evidence from cause-specific deaths and early childhood mortality.

Francisca AnTman, University of Colorado Boulder

\section{Economic Consequences of Childhood Exposure to Environmental Toxins: A Case Study of Lead Service Pipes in Massachusetts}

The leaching of lead into drinking water through lead plumbing in the late nineteenth and early twentieth century represents a period of immense exposure to an environmental toxin that has damaging health consequences. Using historical data on the type of water infrastructure used in towns in Massachusetts and the 1900 and 1940 U.S. Census, I exploit variation in the type of material used for pipes that connected water mains to households to determine how childhood exposure to lead affects an individual's educational attainment and labor market success. I find that living in towns with lead plumbing leads to a 9 percent decrease in the probability that a male is attending school in 1900, a decrease of 1.3 years of completed education in 1940, and a 15 percent decrease in annual wages in 1940.

Gisella Anne Kagy, Vassar College

Water Quality, Morbidity, and Mortality in London, 1906-1926

This paper examines the effects of chlorination on typhoid fever morbidity and mortality rates in London during the early decades of the twentieth century using a newly constructed panel data set at the borough-by-quarter-of-year level. A differencein-differences identification strategy takes advantage of variation in the sources of water supply and the introduction of chlorination across parts of London in 1916. I find that chlorination accounts for 16 to 29 percent of the decline in the typhoid mortality rate during the sample period, with larger effects in the fourth quarter of the year when 
contaminated river water entered the water supply due to flooding. This study contributes to the empirical literature on the effects of improved sanitation infrastructure and the historical debate over the causes of the mortality decline in England and Wales during the late-nineteenth and early-twentieth centuries.

AnTHONy Wray, Hitotsubashi University

\section{SESSION 8: RELIGION, INSTITUTIONS, AND ECONOMIC GROWTH}

The Making of a Liberal Education: Political Economy of the Austrian School Reform, $1865-1875$

Modern economic development is closely tied with the emergence of modern schooling. However, schooling systems are expensive to build and to maintain and, as publicly financed service, they are also subject to intense political battles. We propose to evaluate who was for and who against the extension of schooling by investigating the actual parliamentary voting on a liberal school reform passed in the Austrian Empire in May 1869. Our dataset contains the voting records of all the members of the parliament on all proposed amendments and the final vote, their personal characteristics and the demographic, economic, and educational variables of their districts. We argue that the landed interests opposed the reform because the reformed schooling would encourage the emigration of (now more educated) rural labor force to industrializing cities. Thus, through the reform, the industrial districts voted themselves an implicit subsidy: the countryside would pay for educating future industrial workers.

Tomas Cvrcek, University College London, and Miroslav ZajiceK, Vysoka skola ekonomicka v Praze

\section{Jewish Communities and City Growth in Preindustrial Europe}

We study whether cities with Jewish communities grew faster than cities without Jewish communities in Europe between 1100 and 1850. We match data on city populations from Bairoch (1988) with data on the presence of a Jewish community from the Encyclopedia Judaica. Our OLS results indicate that cities with Jewish communities grew between 5 and 10 percent faster than comparable cities without Jewish communities, but that this effect does not emerge until after 1600 . To establish causality, we create time varying instrumental variables which rely only on the spatially extended network of Jewish communities in order to predict Jewish presence in a given city. We also provide evidence that the Jewish city growth advantage stemmed in part from their ability to exploit increases in market access after 1600 .

NoEl JohnSON and Mark Koyama, George Mason University

\section{State Capacity and Public Goods: Institutional Change, Human Capital, and Growth} in Early Modern Germany

What are the origins and consequences of the state as a provider of public goods? We study legal reforms that established mass public education and increased state capacity in German cities during the 1500s. These fundamental changes in public goods 
provision occurred where ideological competition during the Protestant Reformation interacted with popular politics at the local level. We document that cities that formalized public goods provision in the 1500s began differentially producing and attracting upper tail human capital and grew to be significantly larger in the long run. We study plague outbreaks in a narrow time period as exogenous shocks to local politics and find support for a causal interpretation of the relationship between public goods institutions, human capital, and growth. More broadly, we provide evidence on the origins of state capacity directly targeting welfare improvement.

JEREMIAH E. DitTMAR, $L S E$, and

Ralf R. Meisenzahl, Federal Reserve Board

\section{SESSION 9: HEALTH AND NUTRITION}

\section{Nutrition and Southern Welfare: Evidence from the Boll Weevil and State Level Fortification Laws}

This paper examines the effects pellagra, a disease caused by insufficient niacin consumption, on a variety of health-related outcomes in the American South during the first half of the twentieth century. The analysis draws on detailed county level data spanning 1915-1950 and an intensity of treatment approach. We have three main findings. The first two findings build off an historical literature that says the arrival of the boll weevil improved Southern diets, particularly in high cotton producing. First, in North Carolina counties, the arrival of the boll weevil between 1919 and 1922 caused pellagra mortality, infant mortality, and all age mortality to fall. The effects were larger for counties with higher pre-boll weevil pellagra mortality rates and higher pre-boll weevil shares of land in cotton production. Second, over the period 1915-1921, the heights of white, southern born men who were drafted into the Army during WWII, rose after the boll weevil arrived in counties and rose more in boll weevil counties with higher shares of land in cotton production. Third, in Southern states the passage of mandatory fortification laws during the 1940s caused pellagra mortality, infant mortality, and all age mortality to fall. Fortification saved 2,030 infants per year. These results suggest that nutritional interventions played an important role in short- and longer-run improvements in Southern health.

\section{Karen Clay, Carnegie Mellon, ETHAN SCHMick, and Werner Troesken, University of Pittsburgh}

\section{Bismarck's Health Insurance and the Mortality Decline}

The contribution of public health investments to demographic change and economic growth is much debated. We investigate the impact on mortality of the world's first compulsory health insurance, established by Otto von Bismarck, Chancellor of the German Empire, in 1884. Using Prussian administrative panel data, we exploit differences in eligibility for health insurance across occupational groups. Results from generalized difference-indifferences models suggest that a significant and large reduction of blue collar workers' mortality (the compulsory insured group) occurred directly after the introduction of the health insurance. Findings are robust to alternative control 
groups and competing explanations of mortality declines. Heterogeneous reductions of mortality by gender, age, and cause of death point to potential intra-family spillovers of insurance benefits.

\section{Stefan Bauernschuster, University of Passau, Anastasia Driva, LMU Munich, and ERIK HORNUNG, University of Bayreuth}

\section{Sweet Blood: A New Peril of Rapid Economic Growth}

Economists are raised to believe that rapid economic growth is a noble quest that can help alleviate the grinding hardships of poverty. Of course, growth has recognized costs such as pollution, congestion, and resource depletion. Here I add a new cost to the list: chronic non-infectious adult diseases and specifically type 2 diabetes. This paper develops implications of the fetal origins hypothesis, which can explain the formation of permanent biological human capital, i.e., organs such as the cardiovascular system, the kidneys and the pancreas, which are constructed in utero and adapted to the environment the newborn child is expected to inhabit. I apply these ideas to understand the high prevalence of type 2 diabetes in the American South and in numerous countries with a recent past of rapid development. The limited biological adaptability of the human species creates irreversible health vulnerabilities in times of rapid economic growth.

Richard Steckel, Ohio State University

\section{SESSION 10: FINANCIAL CRISIS: CAUSES AND CONSEQUENCES}

\section{International Liquidity Shocks, the Real Economy, and Social Unrest: China, 1931-1935}

What are the social consequences of liquidity shocks? We answer this question relying on a natural experiment from 1930s China, where the money supply contracted as a consequence of the 1933 U.S. Silver Purchase program. Using a novel, handcollected data set of loan contracts to individual Chinese firms and labor unrest, we find that the resulting bank liquidity shock led to a widespread, large credit contraction. We also find that firms borrowing from banks with a larger exposure to the monetary shock were more likely to experience labor unrest. These findings support Milton Friedman's (1992) conjecture that the U.S. Silver Purchase program exacerbated social tensions in 1930s China, and contribute to our understanding of the (unintended) social consequences of liquidity shocks.

FABIO BRAGGION, Alberto Manconi, and HAIKUn ZHU, Tilburg University

\section{Estimating the Impact of Local Conditions During the Great Depression on Asset} Preferences in Adulthood

I exploit within state variation in income over time to investigate whether macroeconomic fluctuations at the subnational level have a lasting impact on children. Consistent with beliefs about the notable impact of the Great Depression, children who grew up 
in states with lower average personal income and were exposed to greater state level income shocks invest less into risky assets throughout their lives. Individuals who lived through these adverse conditions were also less likely to be self-employed. Financial conditions during teenage years have the largest impact on risk aversion in adulthood. I provide evidence for these claims using three different datasets: the Panel Study of Income Dynamics, the Survey of Income and Program Participation, and the Health and Retirement Study.

ERIN MCGUIRE, University of Arizona

\section{How to Prevent a Banking Panic: The Barings Crisis of 1890}

Financial histories have treated the Barings Crisis of 1890 as a minor or pseudocrisis, with no threat to the systems of payment and settlement. New evidence reveals that Baring Brothers was a deeply insolvent institution. Just as knowledge of its true condition was revealed and a full-scale panic was about to ignite, the Bank of England stepped in, but it did not respond as Bagehot recommended. Instead of waiting for the panic to break and then lending freely at a high rate on good collateral, the Bank organized a pre-emptive lifeboat operation. A large domestic financial crisis was avoided with no further impact on the real economy, while steps were taken to mitigate the effects of moral hazard from this discretionary intervention.

Eugene N. White, Rutgers University

\section{SESSION 11: HUMAN CAPITAL AND INDUSTRIALIZATION}

\section{Human Capital Formation during the First Industrial Revolution: Evidence from the Use of Steam Engines}

This paper studies the relationship between technological progress and human capital formation during the early phases of the British Industrial Revolution. We adopt the methodology used by Franck and Galor (2016) and perform cross-section regression analyses using county-level variation in the number of steam engines in 1800 as an indicator of technological change. Using exogenous variation in carboniferous rock strata as an instrument for the regional distribution of steam engines, we find that technological progress improved the working skills of the labour force. That is, places with more steam engines had higher shares of skilled labour and of industrial-specific mechanical workers deemed important by Joel Mokyr (2005) for industrialization. Technological progress was, however, not conductive to elementary schooling. Places with more steam engines had lower rates of literacy, numeracy, and school enrollment. These findings highlight the ambiguous effects of the Industrial Revolution on the formation of human capital.

Alexandra de PleiJt, LSE and Utrecht University, Alessandro Nuvolari, Sant' Anna School of Advanced Studies, and $\mathrm{J}_{\mathrm{ACOB}}$ WeISDORF, University of Southern Denmark and CEPR 
The Relevance of Skills to Innovation during the British Industrial Revolution, 1651-1851

This paper assesses the role of human capital in causing the rate of innovation to accelerate during the British Industrial Revolution. In particular, I present new evidence on the skills and education of 677 inventors and innovators in Britain, who were first active between 1651 and 1851. I find that their training and knowledge likely only affected the direction of innovation, but rarely appears to have actually caused them to innovate for the first time. Instead, I identify the spread of a mentality of improvement from person to person, which individuals could act upon regardless of their prior skills. The spread of this mentality of improvement better explains why individuals invented-particularly among a substantial minority whose skills and education had little bearing upon their later innovative activity. Its spread is also demonstrable among those inventors who possessed highly transmissible skills. Where individuals lacked the relevant skills to realize their innovative visions, they engaged in self-education.

Anton Howes, King's College London

\section{Engineers, Innovative Capacity and Development in the Americas}

This paper offers the first evidence on the prevalence of a central actor in modern growth theory - the engineer. Using newly collected sub-national, and international data as well as historical case studies, it then argues that differences in innovative capacity, captured by the density of engineers and patents at the dawn of the Second Industrial Revolution, in fact, are important to explaining present income differences across U.S. counties, states within countries, and between the United States and Latin America. This remains the case after controlling for literacy, other higher order human capital, and demand side elements that might be confounded with engineering or patenting. Instrumenting engineering using the Land Grant Colleges program further limits remaining endogeneity. A 1 SD increase in engineers at the turn of the twentieth century accounts for a 16 percent increase in U.S. county income today, and patenting capacity contributes another 10 percent. This can partly explain why countries with similar levels of income in 1900, but tenfold differences in engineering density diverged in their growth trajectories over the next century.

William Maloney, World Bank, and Felipe Valencia, Bonn University

\section{SESSION 12: LONG-RUN ECONOMIC GROWTH: MACRO AND MICRO PERSPECTIVES}

\section{Understanding the Gains from Trade through the Window of Japan during the Nineteenth-Century Globalization: Analysis of a Natural Experiment}

Many contributions to the literature on the impact of incorporating the global South into the international trading system during the nineteenth century make strong claims about the adverse impacts of globalization on subsequent economic development. While most of the argumentation about trade and growth is framed in dynamic terms, 
the actual analytical frameworks use static reasoning based upon a blend of HeckscherOhlin and Ricardian perspectives. This paper develops an alternative, resource-augmentation general equilibrium framework to measuring Japan's gains from forced entry into the international economy. Employing data on technologies, factor prices, and trade, we can both estimate the actual welfare gains to Japan and make headway towards understanding the importance of Ricardian versus Heckscher-Ohlin forces in determining the gains from its trade with both the South and industrialized North.

\title{
Daniel Bernhofen, American University, and JoHn C. BRown, Clark University
}

\section{A Long History of a Short Block: Four Centuries of Development Surprises on a Single Stretch of a New York City Street}

Economic development is usually analyzed at the national level, but the literature on creative destruction and misallocation suggests the importance of understanding what is happening at much smaller units. This paper does a development case study at an extreme micro level (one city block in New York City), but over a long period of time (four centuries). We find that (i) development involves many changes in production as comparative advantage evolves and (ii) most of these changes were unexpected (surprises). As one episode from the block's history illustrates, it is difficult for prescriptive planners to anticipate changes in comparative advantage, and it is easy for regulations to stifle creative destruction and to create misallocation. If economic growth indeed has a large component for increases in productivity through reallocation and innovation, we argue that the micro-level is important for understanding development at the national level.

\author{
WILLIAM EASTERLY and \\ LAURA Freschi, $N Y U$, and \\ Steven Pennings, World Bank
}

\section{Shrink Theory: The Nature of Long-Run and Short-Run Economic Performance}

Understanding long-run economic performance is a fundamental concern of economic historians. New data on economic performance period suggests that economies vary as least as much in how they "shrink" as in how they "grow." We show that over the long run, reductions in the rate and frequency of shrinking explains much more of the rate of long-run economic performance than the rate of growing when economies grow. The key empirical findings reported here are: (1) In most of the world since 1950, and historically for today's countries where data are available back to the thirteenth century, growing rates and shrinking rates have been high and variable. (2) Long-run economic performance has improved when the frequency and rate of shrinking declined, rather than because the growing rate has increased. (3) When long-run economic performance improves, the short-run rate of growing has normally declines rather than increases.

JoHN WaLLis, University of Maryland, and Stephen Broadberry, Oxford University 


\section{SESSION 13: PATRONAGE AND ADMINISTRATIVE CAPACITY}

\section{The Economic Consequences of Immigrant Disenfranchisement}

While a large literature examines the impacts of electoral enfranchisement, less is known about the effects of disenfranchisement. I address this by estimating the effects of disenfranchisement on voting outcomes, public spending, and crime using a series of state-level provisions which, from 1864 to 1926, disenfranchised non-citizen immigrants in twenty-three states and territories across the United States. I find that disenfranchisement led to an immediate and sustained drop in mayoral and gubernatorial vote totals, but little evidence of effects on measures of partisan electoral outcomes. States significantly reduced their spending directed toward education and social services, and there is suggestive evidence that cities reduced spending on water services. I find that the disenfranchised population was targeted in certain spending reductions: disenfranchisement nearly eliminated the likelihood of recent immigrants obtaining pubic employment. Finally, I present suggestive evidence that disenfranchisement led to an increase in municipal homicide rates.

Morgan Henderson, University of Michigan

Fiscal Capacity, Tax Composition and the (in)Stability of Government Revenues in the Interwar Period

Large and abrupt changes in government revenues can disrupt the functioning of states and increase uncertainty. In the interwar period, and the Great Depression in particular, many countries experienced such events. I investigate how the composition of taxes and fiscal capacity interacted with economic conditions to determine the evolution of government revenues. I find a quantitatively important role for fiscal capacity in reducing their swings. Moreover, this mitigating effect worked through borrowing, rather than through reducing tax revenue volatility. The findings show that governments were significantly constrained in their response to the slump by past investments aimed at building fiscal systems. By presenting a novel data-set on the composition of tax revenues at the central and local level, the paper also contributes to a better understanding of the fiscal history of a period, which marked the beginning of far-reaching changes in the role of governments in the economy.

AndRea PAPAdia, LSE

\section{Weak Administrative Capacity as a Solution to Principal-Agent Problems in Tax Collection}

Tax extraction in Qing China was low relative to Western Europe. It is not obvious why: China was more absolutist and had stronger rights over property and people. Why did the Chinese not convert their absolute power into revenue? We propose a model, supported by historical evidence, suggesting that China's weak administrative capacity, due to its size and poor monitoring technology, is the answer. The center could not ask its tax collecting agents to levy high taxes because it would incentivize agents to overtax 
the peasantry. But they could also not pay agents a high wage because they had no mechanism to commit to not confiscating their resources in times of crisis. A solution was to offer agents a low wage and ask for low taxes while allowing agents to take extra, unmonitored taxes from the peasantry. Low investment in administrative capacity was therefore a strategic substitute for credible commitment.

\author{
DeBIN MA, $L S E$, and \\ JARED RuBIN, Chapman University
}

SESSION 14: CULTURE AND SOCIAL NORMS

\title{
Ethnolinguistic Favoritism in African Politics
}

I document the salience of ethnolinguistic group divisions in African politics with new evidence of favoritism in 142 language groups across 34 countries. I use birthplace coordinates of national leaders and a language map to determine each leader's ethnolinguistic identity, and introduce a computerized lexicostatistical measure that accounts for the relative linguistic similarity of every leader-language pair. As a measure of patronage I use group-level light luminosity between 1992 and 2013. To isolate patronage-specific light variation, I estimate a positive effect of linguistic similarity on night light activity off of changes in the ethnolinguistic identity of a leader. Identification of this effect comes from within-group variation among language groups that were split across national borders during the colonial partitioning of Africa. Using survey data I then distinguish between two mechanisms: a locational mechanism where leaders favor their ethnolinguistic homeland and a preferential access mechanism where individuals benefit irrespective of where they live.

AndRew Dickens, York University

\section{The Evolution of Culture and Institutions: Evidence from the Kuba Kingdom}

We use variation in historical state centralization to examine the impact of institutions on cultural norms. The Kuba Kingdom, established in Central Africa in the early seventeenth century by King Shyaam, had more developed state institutions than the other independent villages and chieftaincies in the region. It had an unwritten constitution, separation of political powers, a judicial system with courts and juries, a police force and military, taxation, and significant public goods provision. Comparing individuals from the Kuba Kingdom to those from just outside the Kingdom, we find that centralized formal institutions are associated with weaker norms of rule-following and a greater propensity to cheat for material gain.

SARA Rachel Lowes, and

Nathan NunN, Harvard University,

JAMES A. RoBinson, University of Chicago, and Jonathan Weigel, Harvard University 


\section{Friends from Afar: Migration, Cultural Proximity, and Primary Schooling in the Lower Yangzi, 1850-1949}

This paper tests the hypothesis that the cultural distance between groups impedes public goods provision. A unique historical dataset of surnames is used to construct a measure of cultural distance between migrants and natives (MNCD) in the Lower Yangzi of China. We exploit the Taiping Rebellion as a quasi-natural experiment where migrants and natives engaged in minimal self-sorting to shorten cultural distance. We find 50 years after the rebellion, at the onset of the campaign for modern education, a one-standard-deviation increase in MNCD is associated with a decrease of 31.7 percent in primary school enrollment rate. Results survive numerous robustness checks, as well as an instrumental analysis exploiting pre-existing cultural distances between local and nearby populations. We propose weakened collective decision-making ability as one of the mechanisms through which migrant-native cultural distance impedes public goods provision. Evidence from the timing of MNCD taking effect, suggests that the primary mechanism runs from migrant-native cultural distance through quality of collective decision-making to modern primary education.

Yu HaO, Peking University, and

Melanie Meng Xue, UCLA Anderson School of Management

\section{SESSION 15: POLITICAL DISORDER AND REVOLUTION}

\section{Surviving the Killing Fields: The Long-Term Consequences of the Khmer Rouge}

In this paper we examine how indirect experiences of atrocities affect a country's nation-building efforts by studying the long-term effect of the Cambodian genocide. About three million people died within three years of the Khmer Rouge leaving millions traumatized by observing atrocities. We identify survivors using high-resolution data on the location of graves and prisons together with pre-genocide socioeconomic and geographic characteristics. To identify a causal effect, we explore variation in genocide exposure using temporal productivity differences. Areas more affected by killings experience higher political competition and more people voting in general elections 35 years following the end of the Pol Pot regime. Using individual-level survey data collected prior to the election in 2013, we find a larger mistrust in the national government as well as lower levels of trust in communes with more casualties.

Mathias Iwanowsky, Institute for International Economic Studies, and Andreas Madestam, Stockholm University

\section{Social Mobility in the Russia of Revolutions, 1850-2015: A Surname Study}

In The Son Also Rises, Gregory Clark shows that social mobility rates can be measured parsimoniously for past societies using surname distributions, and that so measured social mobility is both slow, and invariant to social institutions. Here we apply this method to Russia, using a rich dataset, all students enrolling at Moscow State 
University, 1850-2013. Also, we have access to several million surnames from the modern social website Vkontakte. Russian surname types pre-1917 did indeed vary in average social status, as measured by the shares enrolling at the university relative to the population shares. We can thus measure social mobility rates in Russia before the 1917 Revolution, and the effects of the Revolution on the status of the upper classes in succeeding generations, and after the fall of Communism in 1990. In contrast to Clark, we find that Revolution in Russia did indeed increase social mobility rates.

John V. Nye, George Mason University and NRU-HSE,
MaXym Bryukhanov, Sergiy Polyachenko, and
Vasily Rusanov, NRU-Higher School of Economics

Land Markets and State Capacity in Haiti, 1928-1944

Markets and state capacity in many poor countries are undeveloped and impede growth. Good policy relies on understanding why they are underdeveloped. For Haiti, many theories on underdevelopment have been proposed, but few have been tested because of sparse data availability. I use new data I collected on land markets and state capacity in early twentieth century Haiti to test some of these theories. To discern between theories, I exploit a state land rental program and the unexpected 1937 Trujillo Massacre, which induced a large refugee crisis. The shock created a large demand for state land and slowed public good provision. These effects weaken some of the accepted explanations for Haiti's underdevelopment.

Craig Ogden Palsson, Yale University

\section{SESSION 16: INFRASTRUCTURE AND DEVELOPMENT}

\section{The Impact of Commuting and Mass Transport on the London Labour Market: Evidence from the New Survey of London Life and Labour}

This paper uses detailed information about home and workplace locations contained in the New Survey of London Life and Labour, a 1928-1932 working class household survey, to explore the impact of commuting and the availability of mass transport on the London labour market. We use the GIS coordinates of workers' home and work addresses and of London Underground Stations to construct measures of distance commuted and workers' access to public transport. We find a positive relationship between commuting distance and earnings, and that this relationship was stronger for secondary workers than for household heads. A one kilometre increase in commuting distance increased earnings by about 0.4 percent to 0.9 percent. We also find that, holding constant distance commuted, being located one kilometre closer to an underground station increased the earnings of household heads by slightly more than 1 percent, but had no effect on the earnings of non-heads.

Jessica Bean, Denison University, ANDREW J. SELTZER, and JonAthan WaDSWORTh, Royal Holloway, London 


\section{The Value of Rural Electricity: Evidence from the Rollout of the U.S. Power Grid}

This paper exploits the historical rollout of the U.S. power grid between 1930 and 1960 to study the impact of rural electrification on local economies. We find that rural electrification led to increases in agricultural employment and farm populations. This expansion was offset by a contraction in urban industries, as increased demand for rural land drove up local housing costs and crowded-out non-agricultural sectors. The growth in the rural sector was due both to advances in agricultural productivity and improvements in housing quality. Applying a standard Rosen-Roback style model to our reduced form estimates, we derive estimates of the implied value of electricity for agricultural productivity, and the amenity value of residential electricity access. We find that farm access to electricity raised productivity by 35 percent, and that families were willing to forgo 32 percent of annual income to live in an electrified home. The results suggest that the benefits of rural electrification far exceeded the historical costs of extending the grid, and imply that there is large scope to expand rural access in the developing world today.

JoshuA Lewis, University of Montreal, and Edson Severnini, Carnegie Mellon University

\section{The Role of Irrigation in the Development of American Agriculture}

Starting in the 1930s, agriculture in the United States underwent a productivity revolution. We examine the role of irrigation in the marked increase in farm productivity and distinguish the effects of surface water from groundwater. The Bureau of Reclamation expanded surface water infrastructure immensely beginning with the completion of the Hoover Dam in 1935. Meanwhile, rural electrification and the advent of the center pivot expanded use of groundwater as well. The development of each has been studied in isolation, but not in an integrative analysis. We use data from the U.S. agricultural census to track measures of irrigation along with measures of farm productivity from 1900 on. To statistically identify the effect of irrigation, we compare counties before and after 1940 based on their potential access to surface water and groundwater defined by physical characteristics. Results indicate that groundwater provided more growth than surface water projects, but surface water remains more productive.

ERIC EDWARDS, Utah State University, and Steven M. Smith, Haverford College 